\title{
Terpene Response to Pressing, Harvest Date, and Skin Contact in Vitis vinifera
}

\author{
Andrew G. Reynolds ${ }^{1}$, Douglas A. Wardle ${ }^{2}$, and Marjorie Dever ${ }^{2}$ \\ Agriculture Canada Research Station, Summerland, B.C. VOH 1Z0, Canada
}

Additional index words. aroma, flavor, fruit composition, fruit maturity, maceration, monoterpenes, pomace contact, sensory evaluation, wine quality

\begin{abstract}
Vitis vinifera L. cultivars Müller-Thurgau, Muscat Ottonel, Gewürztraminer, and Kerner were studied for 1 year to document changes in fruit terpene levels from berry stage to free-run and press-juice stages. Substantial amounts of free volatile terpenes (FVTs) and potentially volatile terpenes (PVTs) were lost between berry and juice stages. PVTs were higher in press juices of 'Gewürztraminer' and 'Muscat Ottonel' than in freerun juices. In another experiment, juices from 'Miiller-Thurgau', 'Muscat Ottonel', 'Kerner', 'Optima', 'Pearl of Csaba', and 'Siegerrebe', harvested 10 to 20 days after a designated initial harvest date, contained higher FVTs and PVTs than initially. A third experiment with 'Kerner', 'Müller-Thurgau', 'Optima', and 'Siegerrebe' found highest FVTs and PVTs in juices from grapes subjected to skin contact compared with grapes crushed and immediately pressed. Sensory evaluation showed aroma differences between wines from free-run and press juices of 'Miiller-Thurgau' and 'Muscat Ottonel', aroma and flavor differences due to harvest date for all cultivars except 'Pearl of Csaba', and aroma and flavor differences due to skin contact for 'Siegerrebe'.
\end{abstract}

Terpenes are partly responsible for the floral and muscat aromas and flavors of grapes. Viticultural techniques such as trellising and vine spacing (Reynolds and Wardle, 1991) and basal leaf removal (Reynolds and Wardle, 1989, 1991) influence berry and juice terpene composition, which, in turn, may affect the wine's sensory properties. Other considerations, such as harvest date (Marais, 1987; Marais and van Wyck, 1986), use and duration of skin contact (Bayonove et al., 1976; Cordonnier and Bayonove, 1981; Marais, 1987; Marais and Rapp, 1988; Marais and van Wyck, 1986), and press treatment (Bayonove et al., 1976; Cordonnier and Bayonove, 1979, 1981; Kinzer and Schreier, 1980), have affected terpene concentration significantly in juice and wine.

Many muscat and intensely flavored winegrape cultivars (e.g., 'Pearl of Csaba', 'Siegerrebe', and 'Optima') grown in the Okanagan Valley, B.C., present winemaking problems due to their fruit maturation patterns. In warm years, it may be necessary to harvest these cultivars at low soluble solids concentrations ( $<17^{\circ}$ 'Brix $)$ and titratable acidity (<6.0 g.liter $\left.{ }^{-1}\right)$ and high $\mathrm{pH}(>3.50)$. In many cases, wines made from such fruit may lack varietal character, but delayed harvest could produce wines with a high potential for microbial instability. Extended skin-contact time and using a higher proportion of pressed juice may increase juice and wine terpenes, but these practices are not well accepted by many winemakers.

Received for publication 22 Oct. 1992. Accepted for publication 11 Mar. 1993. Contribution 818. The cost of publishing this paper was defrayed in part by the payment of page charges. Under postal regulations, this paper therefore must be hereby marked advertisement solely to indicate this fact.

${ }^{1}$ Research Scientist.

${ }^{2}$ Research Assistant.
The objectives of these experiments were to assess the effect of harvest date, pressing, and skin contact on the concentration of free and bound terpenes in the juices of several Vitis vinifera cultivars and to relate these data to sensory descriptors of the wines.

Effect of press fraction (Expt. 1). Three 100 -berry and three 250-berry samples of 'Müller-Thurgau', 'Muscat Ottonel', 'Gewürztraminer', and 'Kerner' were collected randomly on 6 Oct. 1987 from five-vine plots in the Agriculture Canada Research Station, Summerland, B.C., cultivar collection and stored at $-40 \mathrm{C}$ until analysis. Fruit harvested for winemaking were stored for $24 \mathrm{~h}$ at $2 \mathrm{C}$, crushed in a destemmer-crusher, and given skin contact for $24 \mathrm{~h}$ at $2 \mathrm{C}$ without sulfite. Fruit were pressed on a hydraulic rack and cloth press with a maximum pressing capacity of $21,100 \mathrm{kPa}$. Approximate juice volumes for 'Müller-Thurgau', 'Muscat Ottonel', and 'Gewürztraminer' were 16, 12, and 16 liters (free-run fractions) and 27, 16, and 11 liters (press fractions), respectively. Free-run and press-juice fractions were blended for 'Kerner'; total volume was 8 liters.

Juices intended for winemaking were sulfited to $50 \mathrm{mg}$ free $\mathrm{S}_{2} \mathrm{O}_{5} /$ liter, stored for 24 $\mathrm{h}$ at $2 \mathrm{C}$, racked, kept at $15 \mathrm{C}$ for $16 \mathrm{~h}$, then inoculated at a rate of $3 \%$ (by volume) with ST61 yeast (provided by C.M. Duitschaever, Univ. of Guelph, Ont.) grown in 'Riesling' juice. Three 250 -ml juice samples were collected from each pressing treatment for each cultivar before inoculation and stored at $-40 \mathrm{C}$ until analysis. Each treatment within cultivar was fermented at $15 \mathrm{C}$ as two replications in 12-liter glass carboys. Fermentation was stopped when residual sugar was $\approx 1.5 \%$, after which wines were cold-stabilized at $-1 \mathrm{C}$ for 3 weeks, racked, and stored at $2 \mathrm{C}$ until bottling.

A 50-g subsample from each 100-berry sample was subjected to the nonvolatile acid extraction procedure of Mattick (1983), and titratable acidity (TA) was determined on the obtained extracts using a Brinkmann Titroprocessor ensemble (Metrohm, Herisau, Switzerland). The rest of the sample was juiced, and soluble solids concentration ( ${ }^{\circ}$ Brix) and $\mathrm{pH}$ were measured on settled juice using an Abbé refractometer (AO Instruments, Buffalo, N.Y.) and a $\mathrm{pH}$ meter (model $825 \mathrm{MP}$; Fisher Scientific, Vancouver, B.C.), respectively. ${ }^{\circ}$ Brix of the juice samples and $\mathrm{pH}$ of the juice and wine were measured in the same manner as those of the berries. Juice and wine TA was measured using the method of Amerine and Ough (1980) using the titrator ensemble noted. Ethanol in the wines was measured using a gas chromatograph (model HP5700; Hewlett-Packard, Mississauga, Ont.). Wines were analyzed after bottling.

Free volatile terpenes (FVTs) and potentially volatile terpenes (PVTs) were determined on two 100-g subsamples of homogenate from the 250-berry samples and on two 100$\mathrm{ml}$ subsamples from each juice sample. The distillation and quantitation procedure used was a modification of the Dimitriadis and Williams (1984) method described by Reynolds and Wardle (1989). Distillation was carried out on a steam distillation unit (model JD-2115; Scientific Glass Apparatus Co., Bloomfield, N.J.), and FVT and PVT levels were determined calorimetrically using a spectrophotometer (model DMS 100; Varian, Georgetown, Ont.).

Wines were tasted by eight experienced wine tasters on 29 May 1989 after 12 months of bottle storage. Seven wines ('MüllerThurgau', 'Muscat Ottonel', and 'Gewürztraminer', each free-run and press; and 'Kerner') were presented in a random order as 50 -ml portions in tulip-shaped clear glasses. The two fermentation replications were presented at separate tastings. Tasters were required to rate the flavor and aroma of each sample according to eight descriptors: muscat, lychee, citrus, green apple, floral, astringent, vegetative, and spicy. Panel members were trained using representative samples of each flavor descriptor (Table 1). A score sheet with 50-mm line scales for each descriptor was used.

Triangle tests also were performed on 'Müller-Thurgau', 'Muscat Ottonel', and 'Gewürztraminer' wines on 20 Nov. 1990 using 10 tasters to ascertain if differences existed between free-run and press treatments. Tasters were asked to identify the odd sample in each case, based exclusively on aroma and flavor, from a trio of wine samples containing two duplicate samples and one odd sample. Tasters assessed aroma and flavor separately and also were asked to identify whether the odd or duplicate samples had the most muscat and most floral aroma, flavor, or both. Muscat and floral references are indicated in Table 1. Sample order was randomized for each taster and rerandomized between aroma and flavor assessment.

Statistical analysis for this and the two accompanying experiments was carried out using SAS's (SAS Institute, Cary, N.C.) Gen- 
Table 1. Wine descriptors and standards used by tasters in our experiments.

\begin{tabular}{|c|c|}
\hline$\overline{\text { Descriptor }}$ & References used \\
\hline \multicolumn{2}{|l|}{ Muscat } \\
\hline Aroma & $\begin{array}{l}\text { Two drops each of linalool, geraniol, nerol, and citral in } 10 \\
\mathrm{ml} 95 \% \text { ethanol, diluted to } 100 \mathrm{ml} \text { with distilled water. }\end{array}$ \\
\hline Flavor & Commercial 1987 'Pearl of Csaba' wine. \\
\hline \multicolumn{2}{|l|}{ Lychee } \\
\hline Aroma and flayor & Lychee nut juice (canned). \\
\hline \multicolumn{2}{|l|}{ Citrus } \\
\hline Aroma & $\begin{array}{l}\text { Two drops of citral in } 10 \mathrm{ml} \text { of } 95 \% \text { ethanol, diluted to } 100 \\
\text { ml with distilled water. } \\
\text { Fresh lemon and lime wedges. }\end{array}$ \\
\hline Flavor & Lemon extract $(1 \mathrm{ml})$ in $200 \mathrm{ml}$ of neutral white wine. \\
\hline \multicolumn{2}{|l|}{ Green apple } \\
\hline Aroma & $\begin{array}{l}\text { Apple extract }(1 \mathrm{ml}) \text { in } 10 \mathrm{ml} \text { of } 95 \% \text { ethanol, diluted to } 100 \\
\text { ml with distilled water. } \\
\text { 'Granny Smith' apple cubes. }\end{array}$ \\
\hline Flavor & Apple extract $(1 \mathrm{ml})$ in $200 \mathrm{ml}$ of neutral white wine. \\
\hline Spicy & - \\
\hline Aroma & $\begin{array}{l}\text { Black pepper, allspice, nutmeg, cinnamon, and whole cloves } \\
\text { ( } 1 \mathrm{~g} \text { each) in } 10 \mathrm{ml} \text { of } 95 \% \text { ethanol. }\end{array}$ \\
\hline Flavor & No reference used. \\
\hline \multicolumn{2}{|l|}{ Floral } \\
\hline Aroma & $\begin{array}{l}\text { Two drops each of linalool and geraniol in } 10 \mathrm{ml} \text { of } 95 \% \\
\text { ethanol, diluted to } 100 \mathrm{ml} \text { with distilled water. }\end{array}$ \\
\hline Flavor & $\begin{array}{l}\text { Two drops each of linalool and geraniol added to } 200 \mathrm{ml} \text { of } \\
\text { neutral white wine. } \\
\text { Commercial 'Riesling' wine. }\end{array}$ \\
\hline \multicolumn{2}{|l|}{ Vegetative } \\
\hline Aroma & $\begin{array}{l}\text { Infusion of grape leaves in } 10 \mathrm{ml} \text { of } 95 \% \text { ethanol, added to } \\
200 \mathrm{ml} \text { of neutral white wine. }\end{array}$ \\
\hline Flavor & Experimental 'Semillon' wine. \\
\hline \multicolumn{2}{|l|}{ Astringent } \\
\hline Aroma & No reference required. \\
\hline Flavor & Grape $\operatorname{tannin}(2 \mathrm{~g})$ in $200 \mathrm{ml}$ of neutral white wine. \\
\hline
\end{tabular}

eral Linear Models procedure. Data were analyzed using treatment $\times$ block (within cultivar) as an error term and treatment $x$ cultivar $x$ block as an error term on data pooled across cultivars. Triangle-test data were analyzed using a one-tailed $t$ test.

Juices of the four cultivars tended to be

higher in ${ }^{\circ}$ Brix and lower in TA, FVTs, and PVTs than their berries (Table 2). Enzymatic breakdown of pectins and amylopectins in the grape skins during skin contact could have accounted for the increased ${ }^{\circ}$ Brix from the berry to juice stage, while tartrate precipitation during skin contact, or acids resident in

Table 2. Composition of berries and free-run and press juices of 'Müller-Thurgau', 'Muscat Ottonel', 'Gewürztraminer', and 'Kerner', 1987.

\begin{tabular}{|c|c|c|c|c|c|c|}
\hline Cultivar & Sample source & ${ }^{\circ}$ Brix & $\begin{array}{c}\text { Titratable } \\
\text { acidity } \\
\left(\text { g.liter }{ }^{-1}\right)\end{array}$ & $\mathrm{pH}$ & $\begin{array}{c}\text { Free } \\
\text { volatile } \\
\text { terpenes } \\
\left(\text { mg.liter }^{-1}\right)\end{array}$ & $\begin{array}{l}\text { Potentially } \\
\text { volatile } \\
\text { terpenes } \\
\left(\mathrm{mg} \cdot \text { liter }^{-1}\right) \\
\end{array}$ \\
\hline \multirow{6}{*}{$\begin{array}{l}\text { Gewürz- } \\
\text { traminer }\end{array}$} & & & & & & \\
\hline & Berry & 20.3 & 8.7 & 3.43 & 1.50 & 2.10 \\
\hline & Free-run juice & 22.5 & 7.2 & 3.48 & 0.91 & 1.75 \\
\hline & Press juice & 22.4 & 7.4 & 3.50 & 0.85 & 1.91 \\
\hline & Contrast (berry vs. juice) & $* *$ & $* * *$ & NS & $* *$ & $* *$ \\
\hline & Contrast (free run vs. press) & * & $* * *$ & NS & NS & $* *$ \\
\hline \multirow[t]{3}{*}{ Kerner } & Berry & 22.5 & 10.5 & 3.15 & 1.00 & 3.24 \\
\hline & Juice & 24.0 & 7.9 & 3.18 & 0.78 & 2.33 \\
\hline & Significance & $*$ & $* *$ & NS & $*$ & $*$ \\
\hline \multicolumn{7}{|l|}{ Müller- } \\
\hline \multirow[t]{5}{*}{ Thurgau } & Berry & 19.4 & 9.6 & 3.35 & 0.77 & 2.23 \\
\hline & Free-run juice & 20.9 & 5.1 & 3.42 & 0.88 & 1.93 \\
\hline & First-press juice & 21.0 & 5.3 & 3.41 & 0.86 & 1.81 \\
\hline & Contrast (berry vs. juice) & $* *$ & $* * *$ & $* *$ & NS & * \\
\hline & Contrast (free run vs. press) & NS & * & * & NS & NS \\
\hline \multicolumn{7}{|l|}{ Muscat } \\
\hline \multirow[t]{5}{*}{ Ottonel } & Berry & 19.6 & 8.1 & 3.49 & 2.78 & 7.85 \\
\hline & Free-run juice & 19.6 & 6.0 & 3.32 & 1.30 & 3.62 \\
\hline & Press juice & 20.9 & 5.9 & 3.34 & 1.36 & 3.91 \\
\hline & Contrast (berry vs. juice) & NS & $* * *$ & $* *$ & $* * *$ & $* * *$ \\
\hline & Contrast (free run vs. press) & NS & NS & NS & NS & $*$ \\
\hline \multicolumn{7}{|l|}{ All cultivars } \\
\hline & Contrast (berry vs. juice) & $* * *$ & $* * *$ & NS & $* * *$ & $* *$ \\
\hline & Contrast (free run vs. press) & NS & NS & NS & NS & $*$ \\
\hline
\end{tabular}

$\overline{s, * * * * * * * N o n s i g n i f i c a n t ~ o r ~ s i g n i f i c a n t ~ a t ~} P \leq 0.05,0.01$, or 0.001 , respectively. the skins, may have accounted for reduced TA. FVT and PVT levels decreased substantially between the berry and juice stages. During skin contact, therefore, some of the terpenes in the skins (Gunata et al., 1985) could not be extracted effectively; hence, FVT and PVT levels decreased. Juice $\mathrm{pH}$ was not affected consistently between the berry and juice stages.

${ }^{\circ}$ Brix was slightly lower and TA slightly higher in press juice of 'Gewürztraminer' compared to the free-run fraction, but pressing did not affect juice ${ }^{\circ}$ Brix and TA levels overall (Table 2). Pressing also did not affect juice $\mathrm{pH}$ and FVT levels. 'Muscat Ottonel' and 'Gewürztraminer' (and across all cultivars) juice PVTs were highest in the press fractions. Increases in terpenes in successive press fractions were reported by Cordonnier and Bayonove (1979, 1981) and Kinzer and Schreier (1980). TA, pH, and ethanol in the wines showed no consistent response to pressing (data not shown). Ranges of those variables in the wines were TA, 5.8 to $7.4 \mathrm{~g} \cdot$ liter $^{-1}$; $\mathrm{pH}, 3.37$ to 3.50 ; and ethanol, $12.7 \%$ to $14.2 \%$.

Tasters could distinguish between free-run and press wines of 'Müller-Thurgau' and 'Muscat Ottonel' based on aroma (Table 3). There were no perceived differences in aroma between the treatments of the 'Gewürztraminer' wines, nor were there significant differences between the treatments based on flavor only (data not shown). For 'Muscat Ottonel', higher juice PVTs could have led to a greater flavor reservoir in the press wines for FVT liberation during aging (hence more floral aroma), but the small treatment differences in 'Gewürztraminer' juice PVTs apparently were not adequate to evoke a sensory response.

Tasters also found no differences between the treatments within cultivars for most of the descriptors, with the exception of spicy for 'Muscat Ottonel' aroma and flavor (data not shown), which was higher in press wines. Fruitiness (sum of muscat, lychee, citrus, and green apple) in 'Muscat Ottonel' press wines also was substantially higher than in the freerun treatment, as was total flavor (sum of all descriptors except astringent). When the tasting scores were pooled across treatments to compare cultivars, 'Muscat Ottonel' had the highest levels of citrus and terpenic (sum of muscat, lychee, citrus, floral, and spicy) and total flavor (data not shown). This result was expected, considering the high FVT and PVT levels in the juice. We were surprised, however, that differences could not be detected among cultivars, despite substantial differences in juice FVTs and PVTs.

Effect of harvest date (Expt. 2). Six cultivars (Müller-Thurgau, Muscat Ottonel, Kerner, Optima, Pearl of Csaba, and Siegerrebe) growing in five-vine plots in the research station cultivar collection were chosen in 1988 to investigate the effect of delayed harvest on fruit composition (especially FVTs and PVTs) and wine quality. Vines were trained to a Y-shaped divided canopy (Reynolds et al., 1992) and the two canopies were kept separated by shoot positioning. Two harvest dates (early and late) werechosen for each cultivar. The design was a randomized complete block 
Table 3. Results of significant triangle tests $(\mathrm{N}=10)$ comparing aromas of Vitis vinifera wines vinted in 1987 from free-run (FR) or press (P) juice, 15 Nov. 1990.

\begin{tabular}{lcccccr}
\hline & & \multicolumn{3}{c}{ Correct respondents $^{2}$ (no.) } \\
\cline { 3 - 6 } Cultivar & Correct & \multicolumn{2}{c}{ Strongest muscat } & & \multicolumn{2}{c}{ Strongest floral } \\
\cline { 3 - 7 } & responses & $7^{*}$ & $\mathrm{P}$ & & FR & $\mathrm{P}$ \\
\hline Müller-Thurgau & $7^{*}$ & $2 / 7$ & $3 / 7$ & $6 / 7^{* *}$ & $1 / 7$ \\
Muscat Ottonel & & $2 / 7$ & $4 / 7$ & $4 / 7$ & $2 / 7$ \\
\hline
\end{tabular}

${ }^{2}$ Based on a one-tailed $t$ test.

"**Significant at $P \leq 0.05$ or 0.01 , respectively.

with each vine within a five-vine plot designated as a block, and the early and late-harvest treatments were assigned randomly to one of the two canopies within the vine. The criteria for the early harvest dates were subjective (palatability) and objective [fruit composition indexes ( ${ }^{\circ}$ Brix, TA, and $\left.\left.\mathrm{pH}\right)\right]$ and satisfied the British Columbian grape-maturity standards (Vielvoye, 1991) for $100 \%$ commercial maturity. Late-harvest dates took place from 10 to 20 days after the early harvest dates.

Fruit were harvested from the appropriate cultivars and treatments and handled in the same manner as in Expt. 1. Grapes werepressed to $21,100 \mathrm{kPa}$, and the free-run and press fractions were blended. Two fermentation replications were used for each treatment within cultivar. Wine was made as previously described.

Berry samples were not retained for analysis in Expt. 2, but two 250-ml juice samples were collected at pressing and stored at $-40 \mathrm{C}$ until analyzing for ${ }^{\circ}$ Brix, TA, pH, FVTs, and PVTs. Wines also were analyzed after bottling for TA, $\mathrm{pH}$, and ethanol. Methods of juice and wine analysis were as described.

Differences between the aroma and flavor of the early and late-harvest treatments within each cultivar were ascertained through triangle tests; 15 experienced tasters participated. Wines were evaluated on 14 Jan. 1991, after 18 months of bottle storage. Tastings were conducted in the same manner as the 1990 tasting in Expt. 1. Muscat and floral references are indicated in Table 1.

Using British Columbian commercial grape-maturity standards as a guideline (Vielvoye, 1991), theoretical monetary values (based on ${ }^{\circ}$ Brix, TA, and $\mathrm{pH}$ ) of early harvested 'Müller-Thurgau', 'Muscat Ottonel', 'Kerner', 'Optima', 'Pearl of Csaba', and 'Siegerrebe' were $120 \%, 110 \%, 110 \%, 90 \%$, $100 \%$, and $70 \%$, respectively, of the base prices for those cultivars. Low TA and high $\mathrm{pH}$ in 'Siegerrebe' were caused by delaying the early harvest until a reasonable ${ }^{\circ}$ Brix level was obtained. 'Optima' was harvested too early in error. Thus, five of six cultivars had attained commercial maturity by their initial harvest dates.

Late harvesting increased ${ }^{\circ} \mathrm{Brix}, \mathrm{pH}, \mathrm{FVTs}$, and PVTs and reduced TA (Table 4). All cultivars also experienced a reduction in wine $\mathrm{TA}$ and an increase in ethanol and wine $\mathrm{pH}$ with delayed harvest. Delaying harvest by the number of days specified in this experiment would have resulted in a $30 \%$ increase in commercial value for 'Optima', a 10\% increase for 'Kerner' and 'Siegerrebe', no increase for 'Müller-Thurgau', and a 10\% loss for 'Muscat Ottonel' and 'Pearl of Csaba'.

Increases in ${ }^{\circ} \mathrm{Brix}$ and $\mathrm{pH}$ and decreases in TA during fruit maturation are well documented (La Rosa and Nielson, 1956; Marais, 1987; Marais and Van Wyck, 1986). However, in the case of terpenes, many researchers (Bayonove and Cordonnier, 1970; Dimitriadis and Williams, 1984; Hardy, 1970; Wilson et al., 1984) have reported a plateau or decrease in their concentration in berries after attaining commercial maturity. Under British Columbian conditions, FVTs and PVTs may continue to increase after full maturity is reached in terms of ${ }^{\circ}$ Brix, TA, and $\mathrm{pH}$. Another significant observation is that small increases in ${ }^{\circ}$ Brix may lead to large FVT and PVT increases, which should contribute to greater varietal character. Because these observations may have important organoleptic and commercial implications, maturity standards will need careful revision to accommodate these facts.

Tasters found differences in aroma between wines from early and late-harvested grapes for all but 'Pearl of Csaba' (Table 5). The nature of these differences was more muscat aroma in late-harvested 'Siegerrebe'. Based on flavor, tasters could not discriminate between early and late-harvest treatments in 'Muscat Ottonel', 'Pearl of Csaba', and 'Siegerrebe', but found more floral flavor in late-harvested 'Optima'. The bulk of these significant differences can be ascribed to higher FVTs or PVTs in the initial juices. 'Muscat Ottonel' and 'Siegerrebe' produced significant organoleptic responses despite a lack of treatment differences in juice FVT, suggesting that bottle storage allowed some hydrolysis of PVTs to their odor-active precursors.

Effect of skin contact (Expt. 3). In 1989, four of the six cultivars used in Expt. 2 ('Müller-Thurgau', 'Kerner', 'Optima', and 'Siegerrebe') were chosen to investigate the impact of skin contact on juice composition and wine quality. The 'Muscat Ottonel' and 'Pearl of Csaba' vines used in 1988 died in Winter 1988-89, while the other four cultivars suffered varying degrees of winter injury and concomitant loss in yield potential. Grapes were harvested on 25 Sept. ('Siegerrebe'), 28 Sept. ('Optima'), and 4 Oct. ('Müller-Thurgau' and 'Kerner').

Fruit were crushed as previously described,

Table 4. Effect of harvest date on juice and wine composition ${ }^{2}$ of six Vitis vinifera cultivars, 1988.

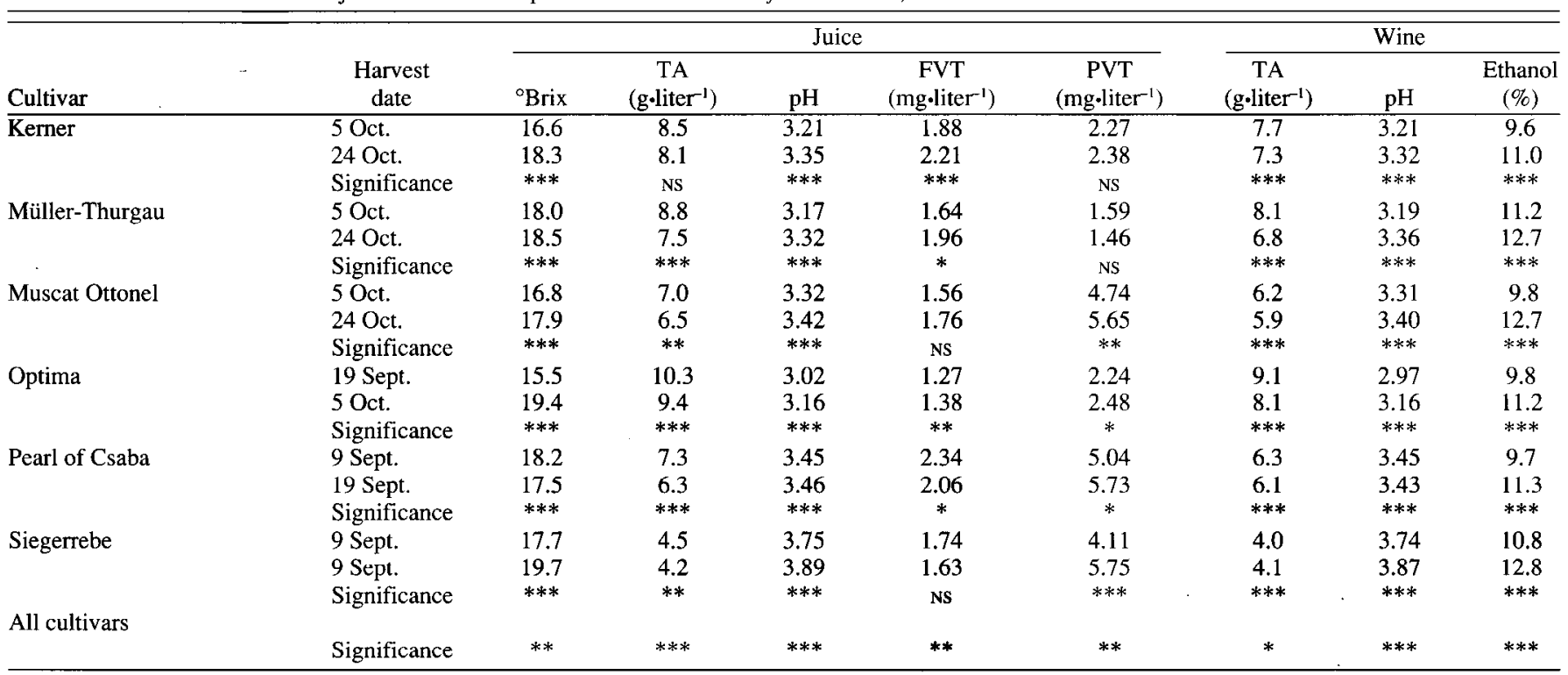


Table 5. Results of triangle tests $(\mathrm{N}=15)$ comparing wines vinted from six Vitis vinifera grape cultivars, each harvested early and late, 1988.

\begin{tabular}{|c|c|c|c|c|c|}
\hline \multirow[b]{3}{*}{ Cultivar } & \multirow{3}{*}{$\begin{array}{c}\text { Correct } \\
\text { responses }\end{array}$} & \multicolumn{4}{|c|}{ Correct respondents ${ }^{2}$ (no.) } \\
\hline & & \multicolumn{2}{|c|}{ Strongest muscat } & \multicolumn{2}{|c|}{ Strongest floral } \\
\hline & & $\overline{\text { Early }}$ & Late & $\overline{\text { Early }}$ & $\overline{\text { Late }}$ \\
\hline \multicolumn{6}{|c|}{ Aroma } \\
\hline Kerner & $13^{* * *}$ & $3 / 13$ & $5 / 13$ & $6 / 13$ & $6 / 13$ \\
\hline Müller-Thurgau & $9^{*}$ & $5 / 9$ & $2 / 9$ & $2 / 9$ & $5 / 9$ \\
\hline Muscat Ottonel & $10^{* *}$ & $3 / 10$ & $1 / 10$ & $2 / 10$ & $5 / 10$ \\
\hline Optima & $11^{* * * *}$ & $2 / 11$ & $4 / 11$ & $4 / 11$ & $5 / 11$ \\
\hline Pearl of Csaba & $7^{\text {vs }}$ & & & & \\
\hline Siegerrebe & $11^{* * *}$ & $3 / 11$ & $7 / 11^{* *}$ & $4 / 11$ & $4 / 11$ \\
\hline \multicolumn{6}{|c|}{ Flavor } \\
\hline Kerner & $15^{* * *}$ & $4 / 15$ & $5 / 15$ & $3 / 15$ & $7 / 15$ \\
\hline Müller-Thurgau & $10^{* *}$ & $1 / 10$ & $2 / 10$ & $3 / 10$ & $3 / 10$ \\
\hline Muscat Ottonel & $6^{\mathrm{Ns}}$ & & & & \\
\hline Optima & $10^{* *}$ & $0 / 10$ & $2 / 10$ & $1 / 10$ & $6 / 10^{*}$ \\
\hline Pearl of Csaba & $5^{\mathrm{vs}}$ & & & & \\
\hline Siegerrebe & $7^{\text {Ns }}$ & & & & \\
\hline
\end{tabular}

${ }^{2}$ Based on a one-tailed $t$ test.

ss,,$* * * * *+$ Nonsignificant or significant at $P \leq 0.05,0.01$, or 0.001 , respectively.

and half of the volume of crushed grapes was given $24 \mathrm{~h}$ ('Optima'), $72 \mathrm{~h}$ ('Siegerrebe'), or $264 \mathrm{~h}$ ('Müller-Thurgau' and 'Kerner') of skin contact without sulfite at $2 \mathrm{C}$. The rest of the fruit (crush-and-press) was pressed immediately and treated as in Expt. 2, except Steinberg yeast (Red Star Co., Milwaukee) was used instead of ST61. Crushed grapes subjected to skin contact were treated during and after pressing in the same manner as the crush-andpress grapes. Two 250-ml juice samples were collected from each treatment within cultivar at pressing and stored at $-40 \mathrm{C}$ until analysis for ${ }^{\circ}$ Brix, TA, pH, FVTs, and PVTs. Two, 12liter fermentation replications were maintained for 'Optima' and 'Siegerrebe'. Insufficient volumes of 'Kerner' and 'Müller-Thurgau' juice were available for winemaking treatments.

Berries and juices were analyzed as described for Expt. 1. Wines were analyzed after bottling for TA, pH, and ethanol as in Expt. 1.

Wines were tasted in Feb. 1992 after 20 months of bottle storage. Differences between the crush-and-press and skin-contact treatments were ascertained by 12 experienced tasters using triangle tests. Tastings were conducted as in Expt. 2. Muscat and floral references are shown in Table 1.
Using skin contact reduced juice and wine TA and increased juice and wine $\mathrm{pH}$ and juice FVTs, PVTs, and ethanol (Table 6). Reduced TA, as in Expt. 1, may be explained by some precipitation of tartaric acid during skin contact, while elevated FVTs and PVTs in skincontact juices could be ascribed to greater extraction of FVTs and PVTs by skin contact. This phenomenon was observed by Marais (1987), Marais and Rapp (1988), and Marais and Van Wyck (1986) on several V. vinifera cultivars in South Africa, although Rapp et al. (1985) could not demonstrate an increase in wine terpenes in response to varying skincontact times.

Tasters could distinguish $(\mathrm{P} \leq 0.05)$ between the crush-and-press and skin-contact treatments for 'Siegerrebe' based on aroma $(15 / 24)$ and flavor (14/24). Skin-contact wines seemed to contain the most floral aroma (8/ 15), a result that corresponded well with the higher juice PVT levels. Tasters could not distinguish between treatments for 'Optima' wines, despite higher juice FVTs and PVTs in the skin-contact treatment (data not shown).

Data presented in these three somewhatrelated experiments provide strong evidence that calorimetric determination of monoterpe- nes can be used to 1) more accurately assess grape maturation than conventional harvest indexes and 2) predict or define the degree of varietal character in wines of some cultivars. Instances of a lack of correlative relationships between monoterpene levels and taster response may be ascribed to stimulus error or to the variability commonly encountered in organoleptic analysis. This lack of correlation also can be explained by the analysis itself, since FVTs and PVTs do not provide a total explanation of the aroma and flavor of the grape cultivars studied here. Although more sophisticated techniques and equipment are available for monoterpene quantitation, the method used in this study should be considered for medium to large wineries or for research programs lacking funds or time for flavor research.

\section{Literature Cited}

Amerine, M.A. and C.S. Ough. 1980. Methods of analysis of musts and wines. Wiley, New York.

Bayonove, C.L. and R.E. Cordonnier. 1970 Recherches sur l'arôme du muscat. I. Evolution des constituants volatils au cours de la maturation du "Muscat d'Alexandrie". Annales Technol. Agr. 10:79-93.

Bayonove, C., R. Cordonnier, P. Benard, and R. Ratier. 1976. L'extraction des composes de l'arôme du muscat dans la phase préfermentaire de la vinification. C.R. Acad. Agr. France 62:734-750.

Cordonnier, R. and C. Bayonove. 1979. Les composantes variétales et préfermentaires de l'arôme des vins. Rev. Oenol. Franc. 16:79-90.

Cordonnier, R.L. and C. Bayonove. 198 1. Etude de la phase préfermentaire de la vinification: Extraction et formation de certains composes de l'arôme; cas des terpenols, des aldehydes, et des alcohols en $\mathrm{C}_{6}$ Connaissance Vigne Vin 15:269286.

Dimitriadis, E. and P.J. Williams. 1984. The development and use of a rapid analytical technique for estimation of free and potentially volatile monoterpene flavorants of grapes. Amer. J. Enol. Viticult. 35:66-71.

Gunata, Y.Z., C.L. Bayonove, R.L. Baumes, and R.E. Cordonnier. 1985. The aroma of grapes. Localisation and evolution of free and bound fractions of some grape aroma components cv. Muscat during first development and maturation. J.. Sci. Food Agr. 36:857-862.

Table 6. Effect of skin contact on juice and wine composition ${ }^{z}$ of four Vitis vinifera cultivars, 1989.

\begin{tabular}{|c|c|c|c|c|c|c|c|c|c|}
\hline \multirow[b]{2}{*}{ Cultivar } & \multirow[b]{2}{*}{ Treatment } & \multicolumn{5}{|c|}{ Juice } & \multicolumn{3}{|c|}{ Wine } \\
\hline & & ${ }^{\circ}$ Brix & $\begin{array}{c}\text { TA } \\
\left(\mathrm{g} \cdot \text { liter }^{-1}\right)\end{array}$ & $\mathrm{pH}$ & $\begin{array}{c}\text { FVT } \\
\left.\text { (mg-liter }{ }^{-1}\right)\end{array}$ & $\begin{array}{c}\text { PVT } \\
\left(\mathrm{mg}^{-} \text {liter }^{-1}\right)\end{array}$ & $\begin{array}{c}\text { TA } \\
\left(\mathrm{g} \cdot \text { liter }^{-1}\right)\end{array}$ & $\mathrm{pH}$ & $\begin{array}{c}\text { Ethanol } \\
(\%) \\
\end{array}$ \\
\hline \multirow[t]{3}{*}{ Kerner } & Crush and press & 23.0 & 12.8 & 2.92 & 0.79 & 2.02 & -- & --- & $\overline{---}$ \\
\hline & Skin contact & 22.2 & 7.9 & 3.20 & 1.62 & 2.76 & 7.1 & 3.26 & 15.4 \\
\hline & Significance & $* * *$ & $* * *$ & $* * *$ & $* * *$ & $* * *$ & --- & --- & --- \\
\hline \multirow[t]{3}{*}{ Müller-Thurgau } & Crush and press & 23.2 & 9.4 & 3.22 & 0.93 & 2.30 & --- & --- & $\ldots$ \\
\hline & Skin contact & 22.6 & 6.8 & 3.37 & 1.36 & 2.36 & 6.2 & 3.27 & 15.6 \\
\hline & Significance & $* * *$ & $* * *$ & $* * *$ & $* *$ & NS & $\cdots$ & -- & -- \\
\hline \multirow[t]{3}{*}{ Optima } & Crush and press & 19.5 & 8.4 & 3.10 & 1.36 & 4.54 & 6.9 & 2.91 & 13.4 \\
\hline & Skin contact & 20.3 & 6.9 & 3.21 & 1.75 & 5.07 & 6.0 & 3.16 & 14.2 \\
\hline & Significance & $* * *$ & $* *$ & $* * *$ & $* * *$ & $*$ & $* * *$ & $* * *$ & $* * *$ \\
\hline \multirow[t]{3}{*}{ Siegerrebe } & Crush and press & 18.9 & 6.0 & 3.37 & 1.88 & 5.16 & 5.2 & 3.13 & 12.8 \\
\hline & Skin contact & 20.6 & 6.5 & 3.44 & 2.04 & 6.10 & 4.6 & 3.28 & 13.1 \\
\hline & Significance & $* * *$ & $*$ & $* * *$ & NS & ** & $* * *$ & $* * *$ & * \\
\hline All cultivars & Significance & NS & $* *$ & $* * *$ & $* * *$ & ** & $* *$ & $* *$ & ** \\
\hline
\end{tabular}

${ }^{\mathrm{r}} \mathrm{TA}=$ titratable acidity, FVT $=$ free volatile terpenes, $\mathrm{PVT}=$ potentially volatile terpenes

Ns,*,**,*** Nonsignificant or significant at $P \leq 0.05,0.01$, or 0.001 , respectively. 
Hardy, P.J. 1970. Changes in volatiles in muscat grapes during ripening. Phytochemistry 9:709715.

Kinzer, G. and P. Schreier. 1980. Influence of different pressing systems on the composition of volatile constituents in unfermented grape musts and wines. Amer. J. Enol. Viticult. 31:7-13.

La Rosa, W.V. and U. Nielson. 1956. Effect in delay of harvesting on the composition of grapes. Amer. J. Enol. 7: 105-1 11.

Marais, J. 1987. Terpene concentrations and wine quality of Vitis vinifera L. cv. Gewurztraminer as affected by grape maturity and cellar practices. Vitis.26:231-245.

Marais, J. and A. Rapp. 1988. Effect of skin-contact time and temperature on juice and wine composition and quality. S. African J. Enol. Viticult. 9:22-30.
Marais, J. and C.J. van Wyck. 1986. Effect of grape maturity and juice treatments on terpene concentrations and wine quality of Vitis vinifera $\mathrm{L}$. cv. Weisser Riesling and Bukettraube. S. African J. Enol. Viticult. 7:26-35.

Mattick, L.R. 1983. A method for the extraction of grape berries used in total acid, potassium, and individual acid analysis. Amer. J. Enol. Viticult. 34:49.

Rapp, A., M. Guntert, and W. Rieth. 1985. Einfluss der Maischestandzeit auf die Aromastoffzusammensetzung des Traubenmostes und Weines. Deutsche Lebensmittel-Rundschau 81:69-72.

Reynolds, A.G. and D.A. Wardle. 1989. Impact of various canopy manipulation techniques on growth, yield, fruit composition, and wine quality of Gewurztraminer. Amer. J. Enol. Viticult. 40:121-129.
Reynolds, A.G. and D.A. Wardle. 1991. Impact of training system, vine spacing, and basal leaf removal on the performance of 'Riesling' vines. Amer. Soc. Enol. Viticult., Seattle 40:27. (Abstr.)

Reynolds, A.G., D.A. Wardle, C. Zurowski, and N.E. Looney. 1992. Phenylureas CPPU and thidiazuron affect yield components, fruit composition, and storage potential of four seedless grape selections. J. Amer. Soc. Hort. Sci. 117:8589.

Vielvoye, J. 1991. Profile of the grape and wine industry of British Columbia. B.C. Ministry of Agr., Food, and Fisheries, Victoria.

Wilson, B., C.R. Strauss, and P.J. Williams. 1984 Changes in free and glycosidically-bound monoterpenes in developing muscat grapes. J. Agr. Food Chem. 32:919-924. 